[Case Report]

\title{
Stabilizing Transpelvic Prosthetic Socket for a Patient with Spinal Cord Injury Sustaining Right Partial Hemipelvectomy and Left Hip Disarticulation
}

\author{
Yoshie NAKanishi ${ }^{1}$, Tetsuro Watanabe ${ }^{2}$, Atsushi $\operatorname{IKedA}^{3}$, Futoshi WadA $^{1}$ and Kenji Hachisuka ${ }^{1}$ \\ ${ }^{1}$ Department of Rehabilitation Medicine, School of Medicine, University of Occupational and \\ Environmental Health, Japan. Yahatanishi-ku, Kitakyushu 807-8555, Japan \\ ${ }^{2}$ Department of Rehabilitation, St. Mary's Hospital. Tsubukuhonmachi, Kurume 830-8543, Japan \\ ${ }^{3}$ Department of Rehabilitation, Kibikogen Rehabilitation Center for Employment Injuries. \\ Kibichuomachi, Kaga-gun 716-1241, Japan
}

\begin{abstract}
A bucket-type transpelvic socket was fabricated for a man with paraplegia from spinal cord injury, who underwent right partial pelvic amputation and left hip disarticulation. His main problem was inability to sit due to asymmetrical pelvic shape. We prescribed a transpelvic prosthetic socket to enable him to sit again. The socket consisted of a dual structure: a hard frame and soft liner. The main features of the socket were redistribution of pressure to prevent recurrence of pressure ulcer, and a slightly backward tilt to maintain a comfortable sitting position. In addition, the socket had small air holes for ventilation; a big window in the abdominal area for management of stoma and cystostomy; and two straps for donning it independently. In addition, we confirmed the internal pressure distribution in the socket by a pressure mapping system to prevent reoccurrence of skin trouble. Finally, the patient regained independence in activities of daily living, including driving a car, after two months of rehabilitative training.
\end{abstract}

Key words : hemipelvectomy, hip disarticulation, transpelvic prosthetic socket, pressure ulcer, spinal cord injury.

(Received January 20, 2012, accepted April 20, 2012) 


\section{Introduction}

Pressure ulcer is a common complication after spinal cord injury (SCI). According to a survey by Krause and Broderick [1], 36\% of patients with SCI experienced pressure ulcer immediately after SCI, and $4 \%$ had a pressure ulcer on an almost constant basis, often requiring hospitalization. Of the 553 veterans with SCI living in a community, 215 (39\%) were diagnosed with a pressure ulcer during a 3-year study [2]. Having at least one skin sore over the 2-year period was associated with lower levels of subjective well-being and activity and greater health problems, and reduced sitting time in response to skin sores was a particularly strong risk factor for poor life adjustment [3].

Although a lot of research on prevention and therapeutic interventions for pressure ulcers after SCI [4] have been reported, it is unusual for hemicorporectomy [5-8], which means a translumbar amputation, hemipelvectomy and hip disarticulation [9-11], to be applied as a life-saving measure to a patient with SCI who sustains life-threatening pressure ulcers, infection in the pelvis, osteomyelitis in the pelvis, and cancerous tumors. Proximal amputation (hemipelvectomy and hip disarticulation) for recurrent pressure ulcers decreases the days of hospitalization necessary for treating pressure ulcers, the number of operations, and the recurrence of pressure ulcer [9], but after proximal amputation, a patient may be ill-shaped, sometimes require further wound debridement and re-resection of bone, and may confront a high risk of complication and mortality in future [10].

To improve disabilities, a prosthesis consisting of a socket with a leg component, or a prosthetic socket without a leg component, was prescribed for patients with bilateral hip disarticulations and hemicorporectomy [7, 12-15]. The prosthetic socket without a leg component has especially been preferred for functional stability and mobility.

We recently prescribed a bucket-type transpelvic socket for an SCI patient who underwent right partial hemipelvectomy and left hip disarticulation as life-saving measures for intractable pressure ulcers in the pelvic area, osteomyelitis, and canceration around the ulcers. The transpelvic prosthetic socket as well as interdisciplinary collaboration between health care professionals and rehabilitation staff was essential for his return to home.

\section{Case description}

A 60-year old man was well until 1975, when he sustained a traumatic SCI and was transferred to the Spinal Injuries Center, Iizuka. After non-surgical and rehabilitative treatments, his functional level turned the first lumber segment, and he was independent in activities of daily living (ADL), and was discharged to home. After several years, he noticed a pressure ulcer at his right great trochanter area, and repeated infection spread, causing osteomyelitis. He underwent right partial hemipelvectomy in 2000 to improve his general condition. Three years later, he also noticed pressure ulcers at the sacral and left great trochanter areas, infection of which expanded into his urethra and rectum, and canceration around the ulcer was confirmed. Finally, in 2003 he underwent construction of an artificial anus, cystostomy, and left hip disarticulation.

Two months after his hip disarticulation, he was referred to the department of rehabilitation 
for further treatment because he was totally dependent in ADL. At the time of admission, he had an artificial anus and an exit of cystostomy in his abdomen, and his residual trunk was asymmetrically pyramid-shaped due to right partial hemipelvectomy and left hip disarticulation (Fig.1). The muscle strength of the upper extremities was normal without any limitation of range of motion, and sensory disturbance was noticed at the buttock. His previous medical history included diabetes mellitus and cataract. From the standpoint of rehabilitation, the most serious problem was the inability to maintain his residual trunk in the upright position, which was the source of various disabilities.

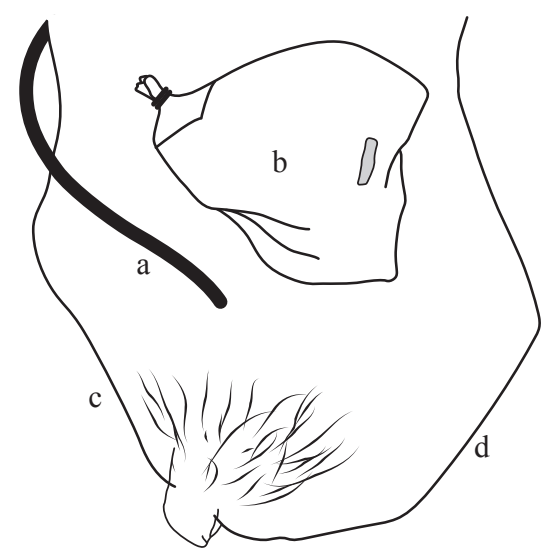

Fig. 1. Residual trunk. a: catheter of cystostomy, b: bag of an artificial anus, c: right partial hemipelvectomy, d: left hip disarticulation.

\section{Transpelvic prosthetic socket}

A bucket-type transpelvic socket was prescribed to help him regain independence in ADL. The purposes of the socket were as follows: 1) maintain his residual trunk in the stable upright position, 2) transfer from bed to wheelchair and from wheelchair to bed, 3) be relieved from a recurrence of pressure ulcer, 4) don and doff the socket by himself, and 5) take care of his stoma and cystostomy by himself. The socket consisted of an outer hard socket made of polymethyl methacrylate reinforced with carbon fibers, and an inner flexible socket made of polyethylene form with a cotton liner and a polyester liner (Fig.2). The weight bearing was total surface bearing because of his asymmetrically pyramidal-shaped stump and for the prevention of recurrent pressure ulcer. After the outer and inner sockets were carefully molded to fit the asymmetrical shape of his residual trunk, these were finally adjusted based on the pressure distribution on the residual trunk measured with a pressure mapping system (F-Scan, NITTA Co., Tokyo). The socket had a self-suspension function due to a catch at his iliac crests. Static alignment was tilted backwards at 15 degrees to keep a stable upright position and to support his body weight on the back wall of the socket to some extent.

To maintain hygiene within the socket, a large number of small air holes for air ventilation were made in the outer and inner sockets, and small ditches were also made on the inside for discharging sweat. A cotton liner between the outer and inner was used to absorb perspiration, and a polyester liner was directly applied to the residual trunk to reduce shear force to the skin. A big window was made in the abdominal area of the outer and inner socket, and liners to manage stoma and cystostomy, and two straps were attached to the distal-lateral portions of the outer socket to be able to don it easily. 


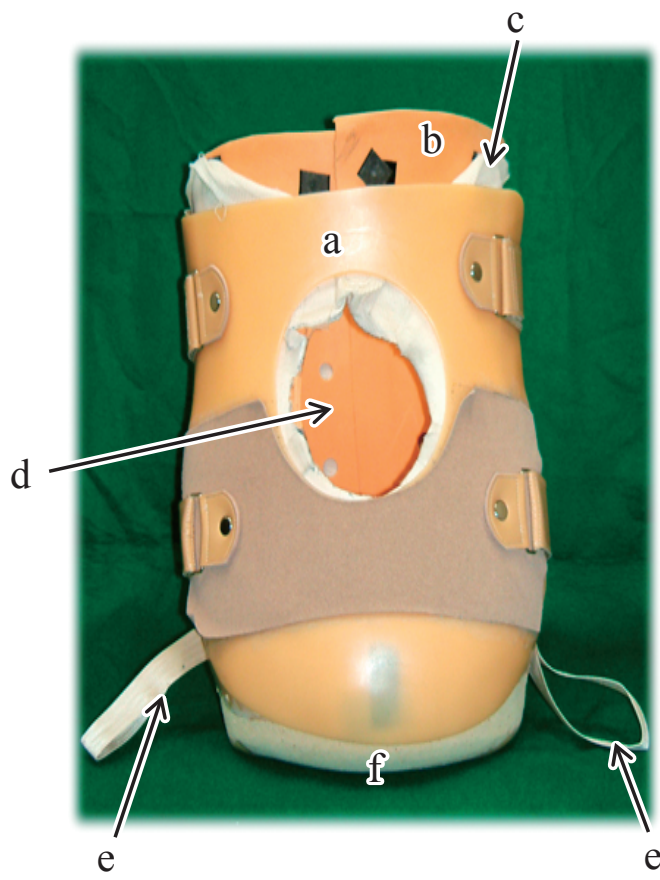

Frontal view

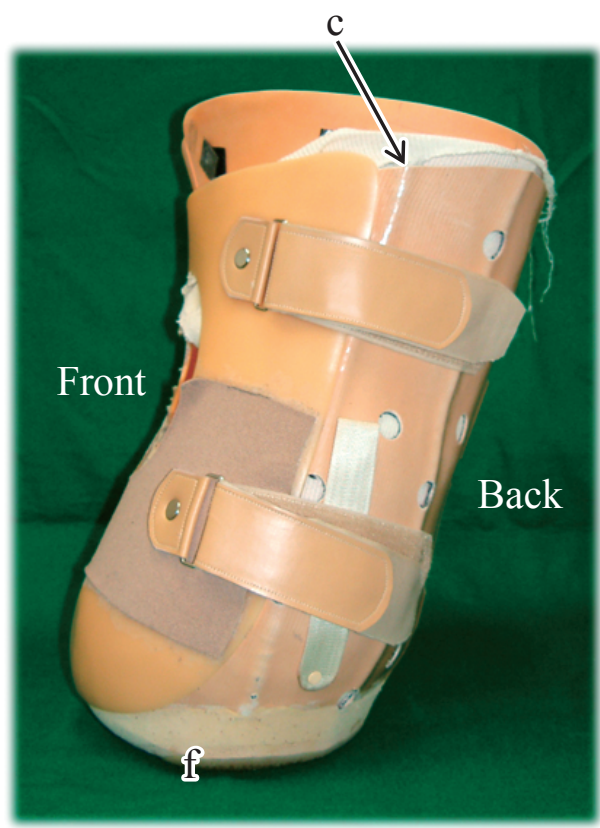

Lateral view

Fig. 2. A bucket-type transpelvic prosthetic socket. a: an outer hard socket made of carbon fiber-reinforced polymethyl methacrylate, $b$ : an inner soft socket made of polyethyleneform, c: a cotton liner between the outer and inner sockets, d: a window for managing stoma and cystostomy, e: straps for pulling up the outer socket, f: sponge to maintain his residual trunk in the upright position. The socket is slightly retroverted but stable.

\section{Results}

The socket fitted well and the patient could sit on the floor (Fig.3). The pressure mapping system showed local pressures on the residual trunk of less than $40 \mathrm{kPa}$ while sitting on a chair (Fig.4). Two points of the outer socket corresponding to the relatively high pressure spots were bulged to reduce local pressure, and no flush or abrasion at the buttock was found after 5-hour daily use.

Wearing the socket, he underwent muscle strengthening exercises for his upper extremities, pushing up exercises, transfer training, and wheelchair training, and he was finally

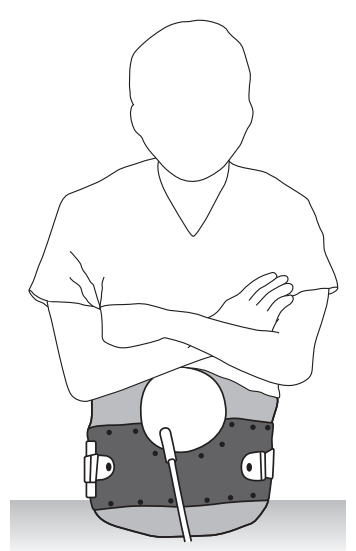

Fig. 3. Sitting on the floor with the socket. 


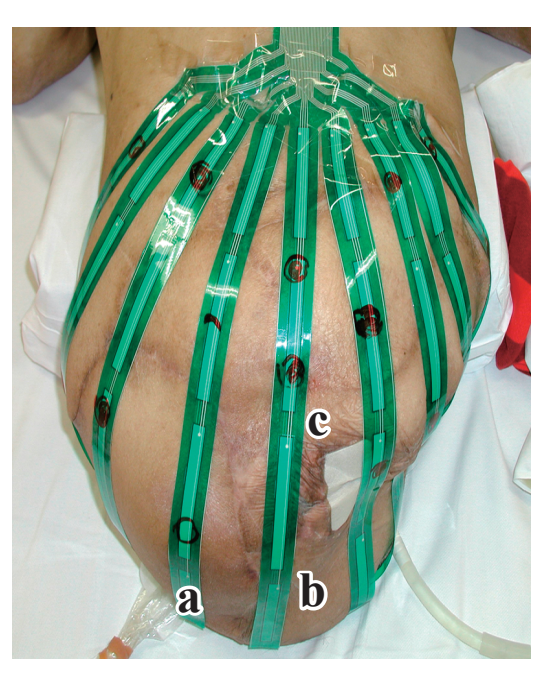

Prone position
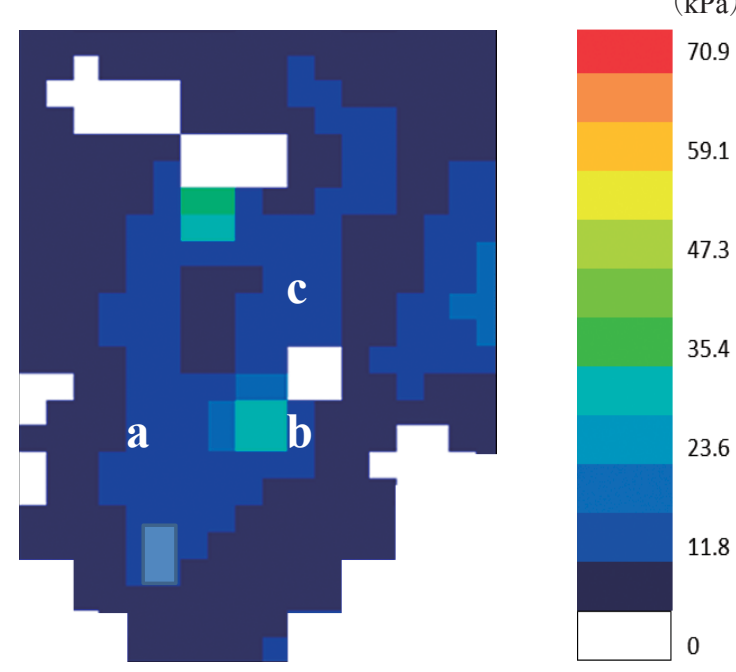

Sitting

Fig. 4. Pressure distribution on the residual trunk. A $0.15 \mathrm{~mm}$-thick flexible pressure tactile sensor sheet was attached to the residual trunk in a radial manner. The pressure distribution was measured while the patient with the socket was sitting on a chair: red color indicates the highest pressure and white color indicates the lowest pressure.

able to don and doff the socket independently. Propelling his wheelchair, he could get about in the hospital. Moreover, he could go anywhere outside of the hospital, because he was able to transfer himself to and from the driver's seat of his own car and drive his car with a manually operated device. He learned how to manage his stoma and cystostomy through the window, and acquired the ability to take care of his skin at the buttock, looking at it in a mirror. He was also advised to wear the socket for 3 hours or less at one time. After 2-month hospitalization, he was discharged to home, being referred to his usual doctor at a local general hospital. According to a report, he was well and had no recurrence of pressure ulcers or skin sores wearing the socket for at least 5 years while he was living at home and working at a sheltered workshop.

\section{Discussion}

The patient with SCI sustaining asymmetrical proximal amputation, that is, right hemipelvectomy and left hip disarticulation, succeeded to return to society, wearing the total surface bearing bucket-type transpelvic socket.

The most important point of rehabilitation for the patient was this socket, which enabled him to sit and extended his daily living and social activities without any help. One serious complication in the use of the socket would be a recurrence of pressure ulcer. To prevent pressure ulcer, the socket should be designed as if for total surface bearing, although with a window, small air 
holes and ditches, and should obtain appropriate pressure distribution on the residual trunk. The data of pressure distribution on the residual trunk were useful to obtain a good fit, especially for a patient with sensory disturbance on the residual trunk. During hospitalization, even if he wore the socket for 6 hours, he never had skin sores on the residual trunk, but we advised him to wear the socket for 3 hours or less at one time at home in order to prevent a pressure ulcer. Because the polymethyl methacrylate reinforced with carbon fibers were lightweight and durable, the socket was desirable for the patient, who lifted his body and socket by his arms. Skin hygiene was essential for the patient, whose residual trunk had sensory disturbance. A double socket with a flexible inner socket is appropriate for a patient with tender skin, and small air holes for ventilation and ditches for discharging sweat, and cotton and polyester liners may be beneficial for skin hygiene. Carlson and Wood reported a flexible air-permeable prosthetic socket consisting of a fabric flexible socket with a rigid frame for bilateral hip disarticulation in patients with SCI [13]. The socket also provided for heat and moisture dissipation, pressure and shear management, and mobility. Bucket-type prosthetic sockets were fabricated for patients with hemicorporectomy[14,15]. Although pressure monitoring equipment was used, detailed explanations were unavailable. To prevent the recurrence of pressure ulcers, it is important to confirm the pressure distribution on the residual trunk while wearing the socket and to get a good fit.

The socket was useful for independence in ADL and return to society during hospitalization, and he was well and had no recurrence of pressure ulcers or skin sores wearing the socket living at home for at least 5 years. However, after he moved to a nursing home, he did not want to use the socket because the care workers helped him.

The pressure mapping system had a limitation. The system used in this study was useful to evaluate perpendicular pressure to the sensor, but not to measure shear force. Therefore, we advised and educated the patient to inspect the skin at the buttock, looking at it in a mirror, after he doffed the socket.

\section{Conclusion}

A patient with SCI sustaining right partial hemipelvectomy and left hip disarticulation was prescribed a total surface bearing bucket-type transpelvic socket, which enabled him to sit and to return to society.

\section{References}

1. Krause JS \& Bronderick L (2004): Patterns of recurrent pressure ulcers after spinal cord injury: identification of risk and protective factors 5 or more years after onset. Arch Phys Med Rehabil 85: 12571264

2. Garber SL \& Rintala DH (2003): Pressure ulcers in veterans with spinal cord injury: A retrospective study. J Rehabil Res Dev 40: 433-441

3. Krause JS (1998): Skin sores after spinal cord injury: relationship to life adjustment. Spinal Cord 36: 51-56 
4. Regan MA, Teasell RW, Wolfe DL, Keast D, Mortenson WB \& Aubut JA (2009): A systematic review of therapeutic interventions for pressure ulcers after spinal cord injury. Arch Phys Med Rehabil 90: 213-231

5. Aust JB \& Page CP (1985): Hemicorporectomy. J Surg Oncol 30: 226-230

6. Kennedy CS, Miller EB, McLean DC, Perlis MS, Dion RM \& Horvitz VS (1960): Lumbar amputation or hemicorporectomy for advanced malignancy of the lower half of the body. Surgery 48: 357-365

7. Porter-Romatowski TL \& Deckert J (1998): Hemicorporectomy: a case study from a physical therapy perspective. Arch Phys Med Rehabil 79: 464-468

8. Shields RK \& Dudley-Javoroski S (2003): Musculoskeletal deterioration and hemicorporectomy after spinal cord injury. Phy Ther 83: 263-275

9. Correa GI, Calderón WO, Burnier LA, Danilla SE, Roa RG \& Guzman LM (2008): Proximal amputation of inferior extremity secondary to recurrent pressure ulcers in patients with spinal cord injuries. Spinal Cord 46: 135-139

10. Chan JW, Virgo KS \& Johnson FE (2003): Hemipelvectomy for severe decubitus ulcers in patients with previous spinal cord injury. Am J Surg 185: 69-73

11. Ziran BH, Smith WR \& Rao N (2008): Hemipelvic amputations for recalcitrant pelvic osteomyelitis. Injury 39: 411-418

12. Oryshkevich RS, Jhee WH, Wilcox R, Coleman D \& Ayyappa E (1984): Sitting orthosis for patient with bilateral hip disarticulation. Arch Phys Med Rehabil 65: 276-278

13. Carlson JM \& Wood SL (1998): A flexible, air-permeable socket prosthesis for bilateral hip disarticulation and hemicorporectomy amputees. J Prosthet Orthot 10: 110-115

14. Wilson JD (2004): A new concept in prosthetic interface design for hemicorporectomy amputees using ROHO compression therapy: a case study from a CPO's perspective. J Prosthet Orthot 16: 104-112

15. Smith J, Tuel SM, Meythaler JM, Cross LL \& Schuch JZ (1992): Prosthetic management of hemicorporectomy patients: new approaches. Arch Phys Med Rehabil 73: 493-497 
脊髄損傷による右部分骨盤切断ならびに左股関節離断の座位保持再獲得のために作 製した骨盤義足ソケット

中西 貴江 ${ }^{1}$, 渡邊 哲朗 ${ }^{2}$, 池田 篤志 ${ }^{3}$, 和田 太 $^{1}$, 蜂須賀 研二 $^{1}$

1 産業医科大学 医学部 リハビリテーション医学講座

2 聖マリア病院 リハビリテーション科

3 吉備高原医療リハビリテーションセンター リハビリテーション科

要旨：脊髄損傷後対麻痺で, 右部分骨盤切除と左股関節離断術を施行した患者に対して, 骨 盤義足ソケットを作製した。重要な問題点は, 骨盤切断端が非対称であることによる座位保持困 難であった。我々は, 座位保持の再獲得を主な目的として, 骨盤義足ソケットを作製した。構成 は, 2 重ソケット式で, 外側は硬く, 内側は柔らかい素材を用いた。特徵として, 裖瘡の再発を予防 するための圧分散を図り, 安定した座位保持のためにソケットをわずかに後方に傾斜させた。加

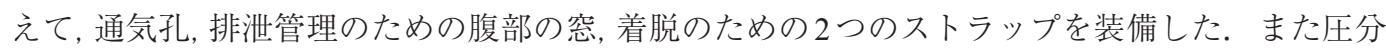
布測定器により断端と装具間の内圧分散を確認し, 皮膚損傷の再発を予防した。患者は2 ケ月間 の機能訓練を行った後, 座位保持を再獲得し, 自動車の運転ができるまで日常生活の拡大が可能と なった。

キーワード：片側骨盤切断, 股関節離断, 骨盤義足ソケット, 裖瘡, 脊髄損傷.

J UOEH（産業医大誌）34（2）：175 - 182（2012） 